\title{
Sudan'da Tasavvufî Hayatın Şekillenmesine Kâdiriyye Ve Şâziliyye Tarikatlarının Etkisi
}

The Effect of Qadiriyya and Shadhili Tariqahs

on the Formation of Șüfì Life in Sudan

Prof. Dr.

\section{Kadir ÖZKÖSE}

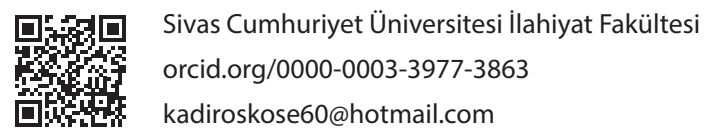




\section{Sufiyge}

164

\section{Öz}

Sudan tasavvufî hayatın etkili olduğu ülkelerden biridir. Ülkede İslâm'ın yayılışı daha çok tarîkat erbabının gayretleri sonucu gerçekleşmiştir. Tarîkatlar zaviye teşkilatları ile Sudan'da geniş halk kitlelerin beklentilerine cevap veren öncelikli kurumlar olarak dikkat çekmektedir. Bölgede tarih boyunca hakim olan tarîkatlar özellikle Kâdiriyye ve Şâziliyye olmuştur. Her iki tarîkat da farklı kol ve şubeleri ile Sudan'da İslâmî kültürün şekillenip gelişmesinde öncelikli rol oynamışlardır. Kâdiriyye ve Şâziliyye tarîkatlarına mensup dervişler Sudan coğrafyasını baştan sona gezmek, halkın arasına karışmak, halkın beklentilerine cevap vermek, farklı kesimlerin kaynaşmasına öncülük etmek suretiyle bölgenin müspet manada gelişimine katkı sağlamışlardır. Kâdiriyye ve Şâziliyye zâviyeleri gerek konumları gerekse işlevsellikleri bakımından canlılıklarını korumuş, ilim ve ticaret merkezi olarak görülmüşlerdir. Kâdiriyye ve Şâziliyye meşayıhı Sudan Müslüman hanedanlıklarının başarılı olmasında, merkezi otoritelerin tesisinde, İslâm'ın yayılmasında, İslâmî bilincin uyanmasında irşad faaliyetleriyle öncülük etmişlerdir. Makalemizde Kâdiriyye ve Şâziliyyenin Sudan'da faaliyet yürüten şubelerini ve önde gelen meşayıhını ele almaya çalı̧tık. Sudan'daki tasavvufî atmosferin şekillenmesinde Kâdiriyye ve Şâziliyyenin etkisini ele almaya çalıştık.

Anahtar Kelimeler: Sudan, Tasavvuf, Tarikat, Kâdiriyye, Şâziliyye.

\section{Abstract}

Sudan is one of the countries where suufî̀ life is influential. The spread of Islam in the country was mostly due to the efforts of the tariqah scholars. Tariqahs attract attention as the primary institutions that respond to the expectations of the large masses of people in Sudan with their zawiya organizations. Qadiriyya and Shadhili are the tariqahs that dominate the region throughout history. Both țariqahs, with their different sects and branches, play a primary role in the formation and development of Islamic culture in Sudan. The dervishes, who are members of the Qadiriyya and Shadhili țariqahs, have contributed to the development of the region in a positive sense by traveling throughout Sudan, mingling with the people, responding to the expectations of the people, and leading the integration of different groups. Qadiriyya and Shadhili orders preserved their vitality in terms of both their location and functionality, and they were seen as centers of science and trade. The Qadiriyya and Shadhili sheikhs pioneered the success of the Sudanese Muslim Dynasties, the establishment of central authorities, the spread of Islam, and the awakening of the Islamic consciousness with their guiding activities. In our article, we will try to deal with the branches of Qadiriyya and Shadhili orders in Sudan and their leading masters. We also touch on the influence of Qadiriyya and Shadhili orders on the formation of the șūfi atmosphere in Sudan.

Keywords: Sudan, Șūfīsm, Țariqah, Qadiriyya, Shadhili. 


\section{Giriş}

Tuzey Afrika'nın fethinden sonra Mısır'ın güneyi istikametinde Kgerçekleşen İslâmî fetihler Müslümanların Sudan coğrafyasında hâkimiyetini sağlamıştır. Kuzeyden gerçekleşen bu fetih hareketleri ile aynı dönemlerde Müslümanların Kızıldeniz üzerinden günümüz Sudan sahillerine ticari seferler düzenledikleri bir gerçektir. Kuzeyden ve doğudan gerçekleşen bu teması sonraki dönemlerde ise Mağrib coğrafyası üzerinden gerçekleşen diplomatik, siyasî, ilmî, ticarî ve içtimaî ilişkiler desteklemiştir. Bölgede İslâm'ın ayılmasında olduğu kadar İslâm kültürünün güçlenmesinde de sûfîlerin öncelikli rolü olmuştur. Tasavvuf ve tarîkatlar Sudan coğrafyasının tarihî bir gerçeğidir. Mısır ve Hicaz üzerinden bölgeye akın eden Müslümanlar arasında sûfî kitleler ilk saflarda yer almıştır. Bölgeye gelen sûfîlerin en önemli özelliği gezginci ve tüccar olmalarıdır. Bölgede varlık göstermeye başlayan tarîkatlar kendilerini Sudan coğrafyasına kolaylıkla adapte etmişlerdir. Halkların beklentilerini karşılayan, sıkıntılarının giderilmesinde halklarla kaynaşan, etnik ve kabile kavgalarının önlenmesinde başarılı olan tarîkatlar Afrika Boynuzuna sirayet etmişlerdir. Öyle ki bölgenin yaşam şartlarına uyum sağlayan tarîkat erbabı iklim koşullarına göre bir çalışma programı uygulamışlardır. Bölge halklarının dil ve kültürlerini yakından tanıyan meşâyih ve müritleri, bölge halkları ile kolayca kaynaşmışlardır. Tarîkatların bölgeye nüfuzları daha çok Sinnar'daki Func Sultanlığı (1504-1821) döneminde gerçekleşmiş, Osmanl1-Mısır yönetiminin deruhte edildiği Ahdi't-Türkiye (1821-1895) ${ }^{2}$ sürecinde ise daha işlevsel hâle gelmiştir. Özellikle on dokuzuncu asırda tarîkatlar geniş zâviye ağlarıyla teşkilatlanmışlar, güçlenmişler, mücadele etmişler ve tasavvufî faaliyetlerine hız kazandırmışlardır. On dokuzuncu yüzyılda tarîkatların birçoğu birer ıslahat ve ihya hareketi olarak asr-1 saadet dönemine dönmeyi hedeflemiş ve bölgede Müslümanların yeniden uyanışına öncülük etmişlerdir. ${ }^{3}$

1. Veli Ertan, Afrika'da ve Avrupa'da İslâmiyet (İstanbul: Bahar Yayınları, 1968), 93.

2. Kavalalı Mehmet Ali Paşa döneminde Osmanlı'nın bölgeye sirayeti ile Osmanlı merkezi yönetim sistemi kurulmuş ve Sudan toprakları Osmanlı valileri tarafından yönetilmiştir. Bu döneme Ahdi't-Türkiye adı verilmektedir.

3. Nicole Grandin, “Sudan, Afrika'nın Boynuzu ve Doğu Afrika'da Tarîkatlar”, İslâm Dünyasında Tarîkatlar: Gelişmeleri ve Aktüel Durumları, çev. Osman Türer haz. Alexandre Popovic - Gilles Veinstein (Ankara: Sûf Yayınları, 2004), 311-314. 
Tasavvufu yeniden düşünmeliyiz diyen Hasan Turabi Sudan'da tasavvufun birleştirici rolüne şu şekilde dikkat çekmektedir: "Sudan'da eskiden bütün halkları birbirine bağlayan bir tasavvuf ekolü vardı. Tasavvufuzun yıllar birleştirici bir unsur olarak var oldu. Müslümanların aralarına ayrılık tohumları ekmek için ortaya çıkarılan en tehlikeli fitneler, Müslümanların sahip oldukları fakl mezhepler üzerinden ortay a atılmaktadır. Bu oyunlar son zamanlarda Şî̀ ve Sünnî Müslümanların aralarını açmak için oynanmaktadır. Tasavvufun 17. ve 18. yüzyılda oynadı̆̆ı birleştirici öğesini bir inceleyin. Bu sadece Sudan'da değil tüm İslâm coğrafyasında da öyleydi. Osmanli'da birliği Nakşîler ve Kädiriler să̆lıyordu. Asya'da yine Çiştîler, Nakşîler ve Kādiriler bunun öncülüğünü yapıyordu. Afrika'da sömürgeciliğe karşı direnen Mehdî ve Senûsî hareketindeki ruhta da bu vardı... Lakin son asırdaki İlâmi hareketler tasavvufa karşı savaş açtı. Bence burada stratejik olarak büyük bir yanlışlı yapıld. Tasavvuftaki ruhu muhafaza etmeliydik."”

Sudan'da etkinlik gösteren tarîkatların en eski ve en yaygın olan Kādiriyye ile Şâziliyye'dir. Kādiriyye'nin şarktan, Şâziliyye'nin garbdan gelerek buluştukları Sudan coğrafyası İslâm dünyasının doğusu ile batısını kültürel zeminde buluşturan adres olmuştur. Sudan toprakları Mağrib ile maşrıktaki manevî gelişimin uyum içerisinde neşv u nemâ bulduğu bir saha haline gelmiştir. Her iki tarîkat da Sudan halklarının ifrat ve tefrite düşmeden Ehl-i sünnet geleneği içerisinde İslâm'a sımsıkı sarılmalarına katkı sağlamıştır. Kādiriyye ve Şâziliyye'nin gerek sosyal hayata doğrudan sirayetleri gerekse ilmî geleneğin husule gelmesine katkı sağlamaları dikkat çeken en bariz ortak noktalarıdır.

\section{Kādiriyye}

Abdülkādir-i Geylânî’nin (ö. 561/1166) ismine izafeten Kādiriyye adını alan tarîkat, günümüze kadar ulaşan en eski tarîkat olmasının yanında, günümüzde de en fazla müntesibe sahip ve en yaygın tarîkatlardan birisi durumundadır. Kādiriyye daha kurucusunun kendi zamanında merkezinden binlerce kilometre uzaktaki diyarlara ulaşmış durumdadır. Hem âlim hem de sûfî olan Abdülkādir-i Geylânî, ilim ve tasavvuf faaliyetlerini birlikte devam ettirmiştir. Sohbet, irşad ve ders halkaları

4. TIMETURK, “Turabi: Tasavvufu Yeniden Düşünmeliyiz” (Erişim 4 Haziran 2008). 
yanında telif ettiği eserlerle de hizmetlerini sürdürmüştür. Abdülkādir-i Geylânî, sünnî tasavvufun sıkı bir takipçisidir. Bu açıdan onun tasavvuf anlayışında zâhir-batın çelişmesi ve çekişmesi yoktur. Kendisinden sonra gelenlerce, başta İbnü'l-Arabî olmak üzere "kutub" ve "insân-1 kâmil" olarak tavsif edilmiştir. ${ }^{5}$

Abdülkādir-i Geylânînnin ilmî, manevî, tasavvufî ve saygın kişiliğii, İslâm dünyasının dört bir yanına yayılan çocuklarının faaliyetleri, müridlerin gayretleri, İslâm toplumunun o dönemki durumu ve Moğol istilâsı gibi etkenler Kādiriliğin kısa zamanda uzak diyarlara kadar yayılmasını sağlamıştır. Tasavvuf tarihinde büyük tarîkatların çoğunda az veya çok, şubelerin teşekkül ettiğine rastlyyoruz. Hakiki olsun, tâlî olsun kendilerini Kādiriliğe nispet eden ve Kādiriliğin kolu sayılan tarîkatları şu şekilde sıralayabiliriz: Hikemiyye, Esdiyye, Beceliyye, Fârıziyye, Ehdeliyye, Gaysiyye, Uceyliyye, Nehâriyye, Zeylaiyye, Tavâşiyye, Müşerriiyye, Yâfiiyye, Cebertiyye, Dâvûdiyye, Urâbiyye, Eşrefiyye, Bekkâiyye, Cüneydiyye, Gavsiyye, Kemâliyye, Kumeysiyye, Nevşâhiyye, Sumâdıyye, Rûmiyye, Bû Aliyye, Nablûsiyye, Hilâliyye, Semmâniyye, Ammâriyye, Nesîmiyye, Resmiyye, Menziliyye, Muhtâriyye, Müştâkıyye, Hâlisiyye, Fâzıliyye, Enveriyye, Niyâziyye, Kesnezâniyye, Mürîdiyye, Kâsımiyye, Mikşâfiyye, Garîbiyye (Hindiyye), Zincîriyye, Şer ${ }^{6}$ iyye. ${ }^{6}$

İslâm'ı yayma çalışmalarını sistematik hâle getiren tarîkatların başında Kādiriyye gelmektedir. Tarîkatın müntesipleri Afrika'da misyonerlerin önünü kesmekle kalmamış, İslâm’ı bölgenin hâkim dini haline getirmişlerdir. Yerli halklar, misyonerlerden çok Kādiriyye gibi tarîkat zümrelerine ilgi ve alâka göstermişlerdir. ${ }^{7}$

Kâdiriliğin Afrika'da ilk intişarı, Abdülkadir-i Geylânî’nin torunu Seyyid Ahmed b. İbrahim'in Bağdat'tan Kahire'ye, oradan da Endülüs'e hicreti ile başlamıştır. Kuzey Afrika'da kısa zamanda intişar eden Kâdiriyye /853/1450)'lerde Fas'ta iyice tanınmıştır. ${ }^{8}$

Tarîkatın ilk intişarından itibaren Afrika'da yoğun bir müntesip edindiği anlaşılmaktadır. Bugün Afrika’nın doğusundan batısına, kuzeyinden

5. H. Kâmil Yılmaz, Anahatlariyla Tasavvufve Tarîkatlar (İstanbul: Ensar Neşriyat, 1994), 136. 6. Adalet Çakır, "Kâdiriyye", Türkiye'de Tarîkatlar Tarih ve Kültür, ed. Semih Ceyhan (İstanbul: İSAM Yayınları, 2018), 170.

7. Jamil M. Abu'n-Nasr, Son Dönem Tasavvuf Akımlarından Tî̀âniyye ve Tekrûr Hareketi, çev. Kadir Özköse (Ankara, TDV Matbaası, 2000), 11.

8. Kadir Özköse, Fas'ta Tasavvufî Hayat (İstanbul: Kalem Yayınevi, 2019), 220-221. 
güneyine kıtanın her tarafında müntesiplerine sıkça rastlanmaktadır. Bu sebeple bazı araştırmacılar Kādiriyyeyi bu kıtadaki en çok müntesibi olan ve en yaygın tarîkat kabul ederler. Sanhâce kabilesi sayesinde tarîkat bir yandan Mağrib'de Takedda'ya kadar yayılırken, diğer taraftan da Merkezi Afrika'da Agades'e kadar uzanmıştır. Tarîkatın Kuzey Afrika'dan iç kesimlere neşrini sağlayan kabile, Kel es-Suk kabilesi olmuştur. Kel es-Suk kabilesi Agallal ve Azavad kentlerini tarîkatın önemli merkezleri konumuna getirmiştir.

Batı Afrika ve Bilâdü's-Sudan'da Kādiriyye tarîkatının yayılmasını sağlayan en güçlü zümre ise Kunta şeyhleri olmuştur. Kunta şeyhleri kendilerini meşhur Kâdiriyye şeyhi Ahmed el-Bekkâ̂̀ye (ö.908/1504) nispet etmişlerdir. Velata şehrini tarîkatlarının merkezi halenine getiren Kunta şeyhleri buradan Timbuktu'yu mesken tutmuşlar, Bilâdü’sSûdân ve Mağrib'den Kayravan, Trablusgarb ve Kahire'ye müritlerini güçlü bir ilmî zümrenin teşekkülüne öncülük etmişlerdir. Timbuktu'da kurdukları medrese ve zaviyeleri ile İslâm'ın güçlü temsilcileri konumuna gelmişlerdir. Muhtâr el-Kuntî'den sonra Kādiriyye Bilâdü's-Sûdân'da Muhtâriyye olarak tanınmaya başlamıştır. ${ }^{9}$ Mağrib ve Bilâdü’s-Sûdân'da Muhtâriyyenin başlıca temsilcilerini; Muhammed b. Ahmed el-Azmûrî (ö. 1284/1867), Beşir b. Abdilhay el-Berbûşî es-Sahrâvî (ö. 1290/1873), Muhammed Emin b. Abdillah el-Haccâcî (ö. 1295/1878), Muhammed Sûdânî (ö. 1308/1891), Muhammed b. et-Tihâmî el-Vezzânî (ö. 1311/1894), Muhammed b. Ahmed el-Merâkeşî (ö. 1318/1901) olarak sıralayabiliriz. ${ }^{10}$

Erken dönemlerden itibaren Sudan coğrafyasında faaliyet yürüten Kādiriyye Hicaz'dan gelen ilk temsilcileri ile varlı̆̆ını görünür boyutta hissettirmiştir. ${ }^{11}$ Kādiriyye tarîkatı zâviye ağlarıyla geçmişten günümüze kadar Hartum, Dongola, Berbera, Tâka, Sinnâr, Kordofan, Darfûr, Bahrü'l-Gazel, Harar, Vaday, Bomu ve Sokoto'da yaygın bir tarîkat haline gelmiştir. ${ }^{12}$ Böylesine güçlü zâviye ağlarıyla Kādiriyye şeyhleri Sudan'da dinamik ve canlı bir faaliyet çizgisi sergilemişlerdir. Diğger tarîkatlara

9. Özköse, Fas'ta Tasavvufì Hayat, 220-221.

10. Abbas b. İbrahim, el-I’lâm bi-men halle ve Merakeş ve Ağmât mine'l-A'lâm, thk. Abdülvehhab Benmansur (Rabat: 1974-1984), 2/77; 7/ 21-29, 68, 91-92, 130-131.

11. J. Spencer Trimingham, A History Of Islam in West Africa (London: Glasgow University Publications Oxford University Press, 1970), 156.

12. Abdurrahman Çaycı, Büyük Sahra'da Türk-Fransız Rekabeti (Ankara: Türk Tarih Kurumu Basımevi, 1995), 22. 
nazaran Sudan halklarıyla daha sıkı bir irtibat içerisinde olmaları Kādiriyye müntesiplerinin oldukça yaygın olmalarına yol açmıştır. Farklı tarîkat zümreleriyle irtibatı sağlamaları, uyumlu kimlikleri, çatışma kültüründen uzak tabiatları, halkla olduğu kadar bürokrasi zümresiyle de yakın temas kurmaları, bölgenin sosyo-kültürel dinamiklerine sahip çıkması nedeniyle Kādiriyyenin Sudan'da bariz bir üstünlüğünün olduğu bilinmektedir. ${ }^{13}$

Kādiriyye müntesiplerinin tarîkat faaliyetleri bir yandan Müslümanların İslâmî kimliklerine sahip çıkmasını sağlarken diğer yandan da on yedinci yüzyıldan itibaren etkisini artırarak devam eden misyonerlik faaliyetlerine karşı İslâm'ın tebliğine zemin hazırlamıştır. ${ }^{14}$ Sudan'da çok sayıda Kādiriyye zümresi bulunmaktadır. Zenciler arasında Kādiriyyenin özellikle üç kolu dikkat çekmektedir. Bunlardan birincisi on beşinci yüzyılda Seyyid Ahmed el-Bekkâî tarafından kurulan Bekkâiyye koludur. İkincisi Kunta şeyhleridir. Üçüncüsü ise Şeyh Muhammed Fâzıl'ın (ö. 1284/1869) kurucusu olduğu Fâziliyye koludur. ${ }^{15}$ Kādiriyye tarîkatının on dokuzuncu yüzyılda varlı̆̆ını daha da güçlü bir şekilde hissettirmesi Kādiriyye müntesibi Osman b. Fûdî’nin Fülânî Hareketi ile Ahmed Bamba'nın mensup olduğu Mûridiyye Hareketi vasıtasıyla olmuştur. ${ }^{16}$ Sudan'ın siyâhî halkları ve özellikle Sahra Tevârıkları arasında faaliyet gösteren Kādiriyye müntesipleri, hac yolculuklarını koordine etmeleri, virdlerini yaygınlaştırmaları, sesli ve coşkulu zikir merasimleri ile Tevârıkların ilgi odağı haline gelmişlerdir. ${ }^{17}$

Mısır ve Hicaz yöresinden gelip Bilâdü’s-Sûdân'da faaliyet yürüten meşâyıhtan en dikkat çeken isim Kādiriyye ve Halvetiyye şeyhi Cibril b. Ömer'dir. İlmi ve takvası ile tanınan Cibril b. Ömer Sudan halklarının maneviyat önderi ve İslâm'ın güçlü bir tebliğcisi olmuştur. ${ }^{18}$ Meşhur halifesi Osman b. Fûdî onun hakkında şu yerinde tespitlerde bulunmuştur:

13. Nicole Grandin, “Sudan ve Doğu Afrika’nın Boynuzu ve Doğu Afrika'da Tarikatlar”, çev. Osman Türer, İslâm Dünyasında Tarîkatlar: Gelişmeler ve Aktüel Durumları, haz. Alexandre Popovic - Gilles Veinstein, (Ankara: Sûf Yayınları, 2004), 326.

14. Ertan, Afrika'da ve Avrupa'da İslâmiyet, 14.

15. Mervyn Hiskett, The Development of Islam in West Africa (New York: y.y., 1984), 50.

16. Annemarie Schimmel, Tasavvuf Notları, çev. Dilara Yabul (İstanbul: Sûfî Kitap, 2018), 91-92.

17. Ahmet Kavas, Osmanlı'nın Merkezi Afrika'ya Açılan Kapısı Fizan Sancağı (İstanbul: Marka Basım, 2018), 132.

18. Osman b. Fûdî, “en-Nesâhu'l-ümmeti-An Islamic Tradition of Reform in the Western Sudan from the Sixteenth to the Eighteenth Century”, ed. Mervyn Hiskett, Bulletin of the School of Oriental and African Studies (London: University of London, 1962), 25-1/3, 589. 
“Cibril b. Ömer'in teşvik ve gayretleri olmasayd, sünnet-i seniyyeye gereği gibi ittiba etmemiz, bid'atın karanliklarından arzulanan kurtuluşu gerçekleştirebilmemiz mümkün olmayabilirdi. Sudan topraklarından batıl inançların ve günah yollarının önünü kesen odur. Biz onun eseriyiz. İcraatlarımız onun projeleridir."19 Osman b. Fûdî başka bir ifadesinde şeyhi Cibril b. Ömer'in hayatını ahlâk-ı hamidenin göstergesi olarak nitelendirmektedir. ${ }^{20}$ Bir diğger müridi Abdullah b. Fûdî ise eserlerinde Cibril b. Ömer’i şeyhler şeyhi ve Bediuzzaman şeklinde değerlendirmektedir. Onun ilim ve irfan sahibi bir zat, yaşadıkları asrın kandili, kapalı kapıların anahtarı ve i’lâ-yı kelimetullah davasına adanmış bir insân-ı kâmil olduğunu belirtmektedir. ${ }^{21}$ Cibril b. Ömer Sudan'da İslâm kültürünün yozlaştırılmasına karşı mücadele vermiş, Müslümanlara karşı uygulanan kimi baskı politikalarına tavır koymuş ve bazı siyâsîlerin İslâm dışı uygulamalarından rahatsız olmuştur. $^{22}$ Konu hakkındaki rahatsızlıklarını şu şekilde dile getirmiştir: "Bizler Sudan diyarlarında siyasîlerin ne tür bir politika izlediklerini, icraatlarının İslâmî mi, gayri İslâmî mi olduğunu yakından takip etmekteyiz. Kıldıkları namazlar, tuttukları oruçlar ve Müslümanlıklarını itiraf etmek suretiyle zulümlerini gizlemeye çalışmaktadırlar. Müslüman olduklarını söylemelerine rağmen, ülkelerindeki bid'at, hurafe ve batıl inançlara karşı vurdumduymaz tutum takınmaktadırlar. Onların bu ilgisiz hâlleri, ülkemizde İslâm dışı âdetlerin yayılmasına yol açmaktadır." ${ }^{23}$ Başka bir değerlendirmesinde ise şunları söylemektedir: "İdarecilerimiz vatanımızda sevapla günahı, sünnetle bid'atı, imanla küfrü bir tutar konuma gelmişlerdir. Onlar zulümlerine, orucun ve namazın aydınlı̆̆ını karıştırmışlardır. Sözde Müslümanlıklarına zavallı ve cahil halkı inandırmışlardır. Hâlbuki onlar Müslüman sayılamaz."24

Cibril b. Ömer'den Halvetiyye icazeti alan Osman b. Fûdî, Muhtar b. Ahmed el-Vâfî el-Kuntî'den (ö. 1226/1811) Kādiriyye icazeti almıştır. İrfânî yaklaşımları ve tezkiye çalışmalarıyla Osman b. Fûdî’nin ıslahat

19. Muhammed Bello, İnfâku'l-meysûr fî̀ tarîhi bilâdi't-Tekrûr (Nijerya: y.y., 1964), 55.

20. Abdullah b. Muhammed, "Ida al-Nusukh", ed. Mervyn Hiskett, Bulletin of the School of Oriental and African Studies 19-3 (1957), 566.

21. İsmail A.B. Balagun, The Life And Works Of 'Uthman Dan Fodio: The Muslim Reformer Of West Africa (Ibadan: y.y., 1975), 32.

22. Kadir Özköse, Nijerya'da Tasavvuf (İstanbul: Kalem Yayınevi, 2019), 59-62.

23. Trimingham, A History of Islam in West Africa, 142.

24. Bello, İnfâku'l-meysûr, 207-208. 
hareketini teşekkül ettirmesinde Muhtar el-Kuntî ilham kaynağı olmuştur. ${ }^{25}$ Tasavvufî ıslahat çalışmasını daha çok günümüz Nijer ve Nijerya topraklarında yürüten Osman b. Fûdî bir Halvetiyye ve Kādiriyye şeyhi olarak Sudan ve Çad topraklarında da etkili olmuştur. Kurucusu olduğu Sokoto Halifeliğinin sınırları Sudan coğrafyasına nüfuz etmiştir. Halvetiyye ve Kādiriyye şeyhleri olarak Osman b. Fûdî, Abdullah b. Fûdî ve Muhammed Bello üçlüsü yetiştirdikleri müritleri ve halifeleri vasıtasıyla on dokuzuncu yüzyılda Kādiriyyenin hâkim konuma gelmesine vesile olmuşlardır. ${ }^{26}$

Sudan'da Kādiriyye tarîkatının bir diğger önemli temsilcisi Şeyh Laminû adıyla da bilinen Muhammed Emin el-Kanimî'dir. Öğrenimini Fizan, Merzûk, Bornu ve Hicaz'da tamamlayan Kanimî, on sekizinci yüzyılın başında Bilâdü’s-Sûdân'da tasavvufî hayatın canlanmasına ve Kādiriyye tarîkatının güç kazanmasına katkı sağlamıştır. ${ }^{27}$ Bornu şeyhi olarak tanınan Kânimî, Ngala şehrindeki zaviyesinde Kādiriyye virdi üzerine irşat faaliyetlerini yürütmüş ve bölgede İslâm'ın yayılışına katkı sağlamıştır. ${ }^{28}$ Aynı dönemde Kādiriyye şeyhi olarak Osman b. Fûdî Sokoto Halifeliğinin kurucusu kabul edilirken, Kanimî bir Kādiriyye şeyhi olarak taşıdığı Kanem-Bornu Devleti'nin hamiliğini üstlenmiştir. ${ }^{29}$

Sudan'da Kādiriyye meşâyıhının en önemli özelliği genelde velûd müellifler olmalarıdır. Kādiriyye zümreleri tarafından kaleme alınan eserler hem Bilâdü's-Sûdân hem de Mağrib coğrafyasında yegâne başvuru kaynakları olarak kabul edilmektedir. Bunlardan bir kısmını şu şekilde sıralayabiliriz: Muhammed Arabî b. Tayyib el-Kādirînnin Tuhfetu ehli's-sıddîka isimli eseri, Abdüsselam b. Tayyib el-Kādirî'nin İğâsetu'llehfân bi-esânîdi evle'l-irfân, el-Maksadu'l-Ahmed, Mu'temidu'r-râvî ile Nuzhetu'l-fikr fî menâkıbi'ş-şahsayni Sidi Muhammed ve vâlidihi Sidi Eb̂̀ Bekr ed-Delâî isimli eserleri, Ahmed el-Kādirî’nin Nesimâtu'l-âs fî̀ hucceti Seyyidinâ Ebi'l-Abbâs Ahmed el-Kādirî isimli eseri, ez-Zuhru'l-bâsim,

\footnotetext{
25. Bello, İnfâku'l-meysûr, 220-221.

26. JF. Ade Ajayi - Ian Espie, A Thousand Years of West African History (London: y.y., 1970), 271; Hiskett, The Development of Islam in West Africa, 160.

27. Hiskett, The Development of Islam, 195.

28. Abdullah Abdurrezzak İbrahim, 'Advau ala't-turuki's-sûfiyye fi'l-Garrati'l-'Ifrikıyye (Kahire: Matbaatu'l-Fenniyye, 1990), 40.

29. Kadir Özköse, "Fülânî Hareketi Önderleri İle Bornu Ulemasından el-Kânimî Arasında Gerçekleşen, Savaş Barış, Tekfir Uhuvvet Tartışmalarının Yer Aldığı Mektuplaşmalar”, Tasavvuf İlmî ve Akademik Araştırma Dergisi (2004), 13/189-230.
} 
Muhammed b. Tayyib el-Kādirî̀nin Neşru'l-mesânî fî ehli'l-karni'l-hâdî aşar ve's-sânî isimli eseri, ${ }^{30}$ Muhammed b. et-Tihâmî el-Vezzânî’nin (ö. 1311/1894) Hatmetü Muhtasari'ş-Şeyh Halil ile Takyîdün fî̀̇mani'l-Mukallid isimli eseri, ${ }^{31}$ Muhammed b. Abdülkerim es-Semmânînnin Risâletünnnefahâti'l-ilâhiyye fî keyfiyyeti sülûki't-tarîkati'l-Muhammediyye ile Risâtetü igâsetü'l-lehfân ve müvâsâti'1-velvân isimli eserleri, Ahmed et-Tayyib'in el-Cevherü'l-ferîd fî ilmi't-tevhîd, Havâssu'l-esmâ ve Risâletün fi'1-kimyâ isimli eserleri bunların en dikkat çekenleridir.

Hartum'a 35 km. kadar uzaklıkta bulunan Umm Davan Bane isimli kasaba bugün bir Kādiriyye şeyhinin emaneti olarak görülmektedir. "Bir 1şık belirdi" anlamına gelen Umm Davan Bane isimli bu kasabaya on dokuzuncu yüzyılda bir Kādiriyye şeyhi gelir. Kasaba halkı onun yaktığı hakikat meşalesinden yararlanır, öncü olur, ışık saçar, kasaba halkının maneviyat yolunu aydınlatır. Verdiği derslerle hakikat ışığını yakar ve cehaletin zifiri karanlıklarını dağıtır. Bölge halkı da bu gerçeği beyan sadedinde işaretle "bir ışık belirdi" demişlerdir. Kasabanın adı böylece ortaya çıkmış ve halen her yıl düzenlenen ihtifallerde kurbanlar kesilmekte, yoksullar doyurulmakta, ikramlar yapılmakta, şeyhin türbesi ziyaret edilmektedir. Kitleler halinde gelen Kādiriyye dervişleri burada buluşup virdlerini icra etmektedirler. Umm Davan Bane halkının ifadesiyle bu kandil 100 yıldır hiç söndürülmeden yanmakta ve şeyhin manevî nüfuzu hâlen devam etmektedir. ${ }^{32}$

\section{2. Şâziliyye}

Kuzey Afrika'da kurulup yayılan tarîkatların en önemlisi Şâailiyye tarîkatıdır. Ebu'l-Hasan eş-Şâzilî (ö. 656/1258) tarafından kurulan Şâziliyye, hemen hemen her dönemde özellikle ilim erbabının rağbet ettiği tarîkat olmuş, Afrika'da kültür ve medeniyet havzasının gelişmesine öncülük etmiş, en çok okunan vird ve hizblere sahip olmuş, şer'î esaslara ciddiyetle bağlı kalmış, Afrika’da Ehl-i sünnet anlayışının güç kazanmasına katkı sağlamış bir tarîkattır. ${ }^{33}$

30. Abdulaziz Benabdillah, Meâlimetu'-Tasavvufi'l-İslâmi (Rabat: Daru Neşri'l-Marife, 2001), 1/56-63. 31. Abbas b. İbrahim, el-íllâm, 7/91-92.

32. Enver Arpa, Afrika Satrancında Sudan: Hatıralar/İzlenimler (Ankara: Meneviş Yayınları, 2013), 205. 33. Grandin, "Sudan ve Doğu Afrika'da Tarîkatlar”, 328. 
Ebu'l-Hasan eş-Şâzilî müntesiplerine marifet, muhabbet, ilim, irfan, murakabe, zühd ve takva esaslarına dayalı bir hayat sürmelerini ögütlemiştir. Ebü'l-Hasan eş-Şâzilî ihlas ve samimiyete verdiği önem gereği olarak tekke, halvet, tâç ve hırka gibi tarikatın şekli unsurlarından çok zühd, takva, irfan ve edeb çizgisine daha fazla ehemmiyet vermiştir. Gündelik hayatın ibadet neşvesi tadında gerçekleşmesini istemiş, zikir ve virdlere hassasiyet gösterilmesini istemiştir, hafî zikir uygulamasını benimsemiştir. ${ }^{34}$ Müritlerin mürşid-i kâmilin halleriyle hallenmesini istemiş, İslâmî esaslarına riayet etmeyi elzem görmüştür. ${ }^{35}$

Şâziliyye tarîkatı Ebü'l-Abbas el-Mürsî, Yâkūt el-Arşî el-Habeşî (ö. 732/1332), Atâullah el-İskenderî (ö. 709/1309), İmam Bûsîrî (ö. 695/1296) ve Dâvûd el-Bâhilî (ö. 730/1330'dan sonra) gibi seçkin simalar tarafından temsil edilmiştir. ${ }^{36}$ Takipçileri tarafından Ebü'l-Hasan eş-Şâzilî’nin fikir ve uygulamaları sistemleştirilmiş ve toplumun her kesimi tarafından kabul edilir bir konuma büründürülmüştür. Temelleri Fas'ta atılan Şâziliyye tarîkatı başta Tunus, İskenderiye ve Kahire gibi şehir merkezlerinde yayılmış ve Mısır'da etkin konuma gelmiştir. Zamanla Kuzey Afrika'nın tamamında yayılan Şâziliyye, İslâm dünyasının en yaygın tarîkatlarından biri konumuna gelmiştir. Yüzden fazla alt kola sahip olan Şâziliyye alt katmanlarıyla sürekli büyümeye devam eden bir tarîkat olmuştur. ${ }^{37}$

Bakâiyye, Hansaliyye, Karzaniyye, Şeyhiyye, Meczûbiyye, Azmiyye, Yeşrutiyye, Cezûliyye, Zerrûkiyye, Darkaviyye, Denderaviyye ve Nâsıriyye tarîkatları Şâziliyye'nin önde gelen kollarıdır. Yüzden fazla kola ayrılan Şâziliyye tarîkatı, Sudan halkının kahir ekseriyeti tarafından benimsenen bir tarîkat olmuştur. Sudan toprakları ve Nil vadisi üzerinde hızla yayılan tarîkat Sudan üzerinden Doğu Afrika'da varlı̆̆ını devam ettirmiş̧tir. ${ }^{38}$ Kādiriyye tarîkatı gibi Şâziliyye tarîkatında da adem-i merkeziyetçi bir yönetim sistemi benimsenmiştir. Şâziliyye tarîkatının Bilâdü's-Sûdân'da

\footnotetext{
34. İrfan Gündüz, Gümüşhanevî Ahmed Ziyâüddîn (K.S.) Hayatı, Eserleri, Tarîkat Anlayışı ve Hâlidiyye Tarîkatı (İstanbul: Seha Neşriyat, 1984), 49.

35. Gündüz, Gümüşhanevî Ahmed Ziyâüddîn, 46-47.

36. Mustafa Salim Güven, "Şâzeliyye”, Türkiye’de Tarîkatlar Tarih ve Kültür, ed. Semih Ceyhan (İstanbul: İSAM Yayınları, İstanbul 2018), 382-383.

37. Ahmet Murat Özel, İbn Atâullah el-İskenderî Hayatı, Eserleri, Görüşleri (İstanbul: İnsan Yayınları, 2014), 24.

38. Nicola A. Ziadeh, Sanisiyah (Leiden: y.y., 958), 4-8.
} 
hızla yayılmasının başlıca sebebi tarîkatın ilim ve irfan, ahlâk ve edep, ibadet ve kulluk çizgisine verdiği ehemmiyettir. ${ }^{39}$

Şâziliyye şeyhlerinden Muhammed Mâdî Ebu'l-Azâim Sudan'da ıslahat fikirlerine bürünüp Şâziliyye'nin Azmiyye kolunun kurucusu kabul edilmiştir. ${ }^{40}$ Nil vadisindeki Dâmir kenti Şâziliyye'nin Meczûbiyye koluna merkezlik etmiştir. Önceleri Kādiriyye tarîkatına mensupken daha sonra Şâziliyye tarîkatına intisab eden Hammad b. Muhammed el Meczûb el-Kebîr, Şâziliyye'nin seçkin bir şeyhi olmuş ve Meczûbiyye'nin kurucusu kabul edilmiştir. Func Sultanlığı döneminde Şâziliyye'nin etkin bir kolu konumuna gelmiştir. ${ }^{41}$ Func Hanedanlığ 1 taraftarı konumundaki Meczûbiyye müritleri 1821 yılında kurulan Türk-Mısır iktidar döneminde muhalif tutumu nedeniyle o dönemin Meczûbiyye şeyhi Muhammed Meczûb es-Sugayyir önce Sevâkin'e daha sonra da Mekke'ye kaçmak zorunda kalmıştır. Mekke'de Ahmed b. İdris'e intisap etmiş ve yaklaşık on yıl kendisine hizmet etmiştir. Ahmed b. İdris'ten icazet aldıktan sonra 1830 yılında tekrar Sevâkin'e dönmüş ve Meczûbiyye'yi artık Şâziliyye'nin bir kolu olarak değil, yeni bir tarîkat pozisyonunda yaymaya çalışmıştır.

1832'de ed-Dâmir'e dönen Muhammed el-Meczûb es-Sugayyir kısa bir süre sonra burada vefat etmiştir. 1821 yılından beri Türk-Mısır iktidarına karşı muhalif tutum sergileyen Meczûbiyye müntesipleri başlangıçtan beri Mehdi'nin zuhur edeceği inancına sahiptiler. 1881 yılında Sudan Mehdisi'nin başlattığı cihada tam teşekküllü destek verip katılan tarîkat özellikle Meczûbiyye tarîkatı olmuştur. Başta ed-Dâmir olmak üzere Beca, Sevâkin, Kassala, Kordofan ve Atbara yörelerinde güçlü konuma gelen Meczûbiyye tarîkatı Ca'liyyîn ve Bişariyyîn gibi büyük kabilelerin topluca intisap ettikleri tarîkat olmuştur. ${ }^{42}$

Şeyh Meczub Mağrib yöresinden bir Mehdi'nin geleceği anlayışını serdetmekteydi. Muhammed Ahmed Mehdi'nin ansızın mehdi olarak ortaya çıkışında Şeyh Meczub'un büyük desteği görüldü. Şeyh Tâhir Meczûb, Mehdî̀nin taraftarlarından Osman Dikna’ya teslim oldu. Şeyh Meczûb’un tarîkatı, Mehdî hareketine dönüştü. Hareketin Mehdiliğe güçlü

39. Grandin, "Sudan ve Doğu Afrika'da Tarîkatlar, 327.

40. Grandin, "Sudan ve Doğu Afrika'da Tarîkatlar”, 367.

41. Grandin, "Sudan ve Doğu Afrika'da Tarîkatlar”, 330-331.

42. Grandin, "Sudan ve Doğu Afrika'da Tarîkatlar”, 345-346. 
desteği olmakla birlikte pek çok taraftarı hayatlarını Osman Dukne'nin gerçekleştirdiği savaşta kaybetmiştir. ${ }^{43}$

\section{Sonuç}

1504 tarihinde kurulan ve Sinnar's başkent edinen Func Sultanlığı, Nubya topraklarındaki Hıristiyan hanedanlığına son verir. Siyahi bir hanedanlık olan Func Sultanlığının ilk hükümdarı Amara Dünkas İslâm âlimlerine kucak açıp ulemanın tebliğ ve irşat faaliyetlerini rahatlıkla sürdürmelerini sağlar. Sudan topraklarının Mısır ve Hicaz'a yakın oluşu bölgede çok sayıda ilim ve maneviyat önderinin faaliyet yürütmesine imkân hazırlar. Hicaz'dan gelen ilim ve gönül önderlerinin özverili çalısmaları sayesinde, İslâm hakkında yüzeysel bilgi ve inanca sahip bölge kabileleri, İslâm'1 içselleştirip İslâmî inançlara bağll lıkta kavi hâle gelirler. Arap Yarımadasından gelen âlimler fakih ve şeyh adıyla itibar görürler, fıkıh, kelâm, hadis, tefsir, kıraat ve belâgat ilimlerinde uzun soluklu tedris faaliyetlerini sürdürürler. Maliki ve Şafii mezhebine mensup ulemanın çalışmaları Ehl-i sünnet anlayışına sahip geniş bir kitlenin vücuda gelmesini sağlar.

Sudan sahasında faaliyet yürüten ulema, aynı zamanda birer sûfî kimliğine sahip olmuşlardır. Halk nazarında onlar keşif ve kerametleri ile tanınmışlar, bereket ehli kimseler olarak görülmüşlerdir. Temsil ettikleri tarîkatlarına, siyaset ve ilim erbabı, köylü ve kentli, kadın ve erkek, zengin ve fakir, genç ve yaşlı, yerli ve yabancı neredeyse her kesimden müntesip kazanmışlardır. Öğrenci ve müritlerinin sayısının kalabalık oluşları onların geniş coğrafyada tesir icra etmelerini sağlamıştır.

Bölgede tasavvufî geleneği en dikkate çeken özelliği zahir ve batın ayrımının olmayışı, medrese ve tekke çatışmasının görülmemesi, muteber tarîkat önderlerinin daha çok ilmî kimlikleri ile ön plana çıkmalarıdır. Tasavvufî anlayışlarda nazariyeden çok amele, fikrî tasavvuftan çok ahlâkî tasavvuf uygulamalarına, felsefî söylemler yerine takva ve ihsan anlayışlarına dayalı tasavvuf bilincine ehemmiyet vermişlerdir.

Geçmişten beri Sudan yöresinde faaliyet yürüten tarîkat meşâyıhının bir diğer özelliği müstakil faaliyet yürütme imkânına sahip olmalarıdır.

43. Trimingham, Islam in the Sudan, 225; İbrahim, 'Advau ala't-turuki's-sufiyye, 87. 
Kuzey Afrika veya Hicaz coğrafyasından birer halife sıfatıyla Sudan'a gelen tarîkat erbabı burada tarîkatlarının müstakil şubelerini oluşturmuşlar, adem-i merkeziyetçi bir usulle hareket etmişler, özerk yapılarını korumuşlardır. Dolayısıyla bölgede yörenin şartlarına uygun çok sayıda tarîkat yapılanmasının meydana gelmesine yol açmışlardır.

Sudan meşayıhına dair zikredeceğimiz bir diğer üçüncü temel özellik onların birer seyyah derviş kitlesi olmalarıdır. Mobil isimler olarak diyar diyar dolaşmışlar, gezginci sûfî taifesi adıyla farklı kabile ve etnik zümrelerin içerisine sirayet etmişler, ilim ve faziletleriyle farklı coğrafyalarda tanınır olmuşlardır. Onların bu gezginci kimlikleri yerleşik hayat sürüp de aile ve kabile çevrelerinin tekke vakıflarına çöreklenme tehlikesinin önüne geçmiş, onların karizmatik şahsiyetlerini yakın çevrelerinin suiistimal etmelerini ortadan kaldırmış, kendileri hakkında çevrelerinde dedikodu oluşturulmasına fırsat vermemiştir. Sudan meşâyıhının gittikleri yerlerde teşekkül ettirdikleri ders halkaları, dolaştıkları köy ve kasabalarda oluşturdukları zikir meclisleri ilgi ve hayranlıkla izlenmelerini sağlamıştır.

Sudan meşâyıhın dördüncü temel özelliği kabileler arası çatışmalarda, aşiretler arası kavgalarda, kitleler arası anlaşmazlıklarda, toplumsal tefrikalarda ve çeşitli guruplar arasındaki anlaşmazlıklarda hakem konumunda olmaları, taraflar arasında barışı temin etmeleri, kitleler arasında yatıştırıcı ve yapıcı rol oynamaları, farklı gurupların kaynaşmasını sağlamalarıdır. Kendilerinin bölgede yaşayan insanlarla aile ve kabile bağları olmadığı, kâmil ve fazıl şahsiyetler olarak tanındıkları için kabileler hakkında verdikleri kararlar genelde kabul görmüş, telkinleri düşmanlıkların önünü almış, kabileler arasındaki kavgaları yatıştırmış ve aralarında anlaşmazlıklar bulunan farklı kitleleri barıştırmıştır.

Sudan meşayıhının beşinci temel özelliği genelde melâmet kimliğine sahip olmalarıdır. Halkın arasına karışmış, gündelik işlerine koyulmuş, çarşı ve pazarlarda geçimlerinin yolunu tutmuş, özel kisve ve kıyafetlerden soyutlanmışlardır.

Sudan meşayıhının bu temel özellikleri özellikle Kādiriyye ve Şâziliyye tarikatlarının ana hususiyetleri olmuştur. Her iki tarikat da kadim geleneği temsil etmeleri bakımından asırlardır Sudan coğrafyasında varlık serüvenini gerçekleştirmişlerdir. İslâm’ın yayılmasında ve İslâm kültürünün şekillenmesinde her iki tarikatın şeyh ve dervişleri öncü rol oynamışlardır. Kādiriyye ve Şâziliyye bölgede teşekkül eden şubeleri ile 
bölge halklarının kaderine müspet anlamda tesir etmiş, bölge halklarının kaynaşmasına katkı sağlamışlardır. Bahsi geçen tarikat meşâyıhı kaleme aldıkları eserleriyle edebî ve kültürel zenginliğin artmasına imkân hazırlamışlardır. Tarikat temsilcileri olarak bölgenin siyasileri ile yakın ilişki kurmuş, bölgede Müslüman hanedanlıkların hükümran sürmesine, merkezi otoritenin hakimiyet kurmasına gayret etmişlerdir. Dervişlerini kendi tasavvufî geleneklerine bağlı kalarak Ehl-i sünnet anlayışı çerçevesinde yetiştirip uzun soluklu eğitim almalarını sağlamışlardır.

Çıkar Çatışması / Conflict of Interest: Yazarlar çıkar çatışması olmadı̆̆ını beyan etmiştir. / The authors declared that there is no conflict of interest.

Finansal Destek / Grant Support: Yazarlar bu çalışma için finansal destek almadıklarını beyan etmiştir. / The authors declared that this study has received no financial support.

\section{Kaynakça}

Abbas İbrâhim. el-İlâm bi-men halle ve Merakeş ve Ağmât mine’l-A'lâm. thk. Abdülvehhab Benmansur. Rabat: y.y., 1974-1984.

Abdullah b. Muhammed. “Ida al-Nusukh”. ed. Mervyn Hiskett. Bulletin of the School of Oriental and African Studies 19-3 (1957). 566.

Abu'n-Nasr, Jamil M. Son Dönem Tasavvuf Akımlarından Tîcâniyye ve Tekrûr Hareketi. çev. Kadir Özköse. Ankara: TDV Matbaası, 2000.

Ajayi, JF Ade - Espie, Ian. A Thousand Years of West African History. London: y.y., 1970.

Arpa, Enver. Afrika Satrancında Sudan: Hatıralar/İzlenimler. Ankara: Meneviş Yayınları, 2. Baskı 2013.

Balogün, İsmail AB. The Life And Works Of 'Uthman Dan Fodio: The Muslim Reformer Of West Africa. Ibadan: y.y., 1975.

Bello, Muhammed. İnfâku'l-meysûr fî̀ tarîhi bilâdi't-Tekrûr. Nijerya: y.y., 2. Baskı, 1964.

Benabdillah, Abdulaziz. Meâlimetu'-Tasavvufi'l-İslâmi. Rabat: Daru Neşri'l-Marife, 2001.

Çakır, Adalet. "Kâdiriyye”. Türkiye’de Tarîkatlar Tarih ve Kültür. ed. Semih Ceyhan. İstanbul: İSAM Yayınları, 2. Baskı, 2018.

Çaycı, Abdurrahman. Büyük Sahra'da Türk-Fransız Rekabeti. Ankara: Türk Tarih Kurumu Basımevi, 1995.

Ertan, Veli. Afrika'da ve Avrupa'da İslâmiyet. İstanbul: Bahar Yayınları, 1968. 


\section{Sufine}

178

Kadir ÖZKÖSE

Fûdî, Abdullah b. Muhammed. "Ida al-Nusukh”. ed. Mervyn Hiskett, Bulletin of the School of Oriental and African Studies 19-3 (1957), 566.

Fûdî, Osman b. Muhammed. “en-Nesâihu'l-ümmeti: An Islamic Tradition of Reform in the Western Sudan from the Sixteenth to the Eighteenth Century”, ed. Mervyn Hiskett. Bulletin of the School of Oriental and African Studies. London: University of London, 1962 25-1/3, 25-3.

Grandın, Nicole. “Sudan, Afrika’nın Boynuzu ve Doğu Afrika'da Tarîkatlar”. çev. Osman Türer İslâm Dünyasında Tarîkatlar: Gelişmeleri ve Aktüel Durumları. haz. Alexandre Popovic Gilles Veinstein. Ankara: Sûf Yayınları, 2004.

Gündüz, İrfan. Gümüşhanevî Ahmed Ziyâüddîn (K.S.), Hayatı, Eserleri, Tarîkat Anlayışı ve Hâlidiyye Tarîkatı. İstanbul: Seha Neşriyat, 1984.

Güven, Mustafa Salim. "Şâzeliyye”. Türkiye’de Tarîkatlar Tarih ve Kültür. ed. Semih Ceyhan. İstanbul: İSAM Yayınları, 2. Baskı, 2018.

Hiskett, Mervyn. The Development of Islam in West Africa. New York: y.y., 1984.

İbrâhim, Abdullah Abdurrezzak. 'Advau ala't-turuki's-sûfiyye fi'l-Garrati’l-'Ifrikıyye. Kahire: Matbaatu'l-Fenniyye, 1990.

Kavas, Ahmet. Osmanlı’nın Merkezi Afrika'ya Açılan Kapısı Fizan Sancă̆ı. İstanbul: Marka Basım, 2018.

Özel, Ahmet Murat. İbn Atâullah el-İskenderî Hayatı, Eserleri, Görüşleri. İstanbul: İnsan Yayınları, 2014.

Özköse, Kadir. Fas’ta Tasavvufî Hayat. İstanbul: Kalem Yayınevi, 3. Baskı, 2019.

Özköse, Kadir. Nijerya'da Tasavvuf. İstanbul: Kalem Yayınevi, 3. Baskı, 2019.

Özköse, Kadir. "Fülânî Hareketi Önderleri İle Bornu Ulemasından el-Kânimî Arasında Gerçekleşen, Savaş Barış, Tekfir Uhuvvet Tartışmalarının Yer Aldığg Mektuplaşmalar”. Tasavvuf İlmî ve Akademik Araştırma Dergisi 13 (2004), 189-230.

Schimmel, Annemarie. Tasavvuf Notları. çev. Dilara Yabul. İstanbul: Sûfî Kitap, 2018.

Trimingham, J. Spencer. A History Of Islam in West Africa. London: Glasgow University Publications Oxford University Press, 1970.

Tımeturk, “Turabi: Tasavvufu Yeniden Düşünmeliyiz”. Erişim 4 Haziran 2008 http: / /www. timeturk.com/Turabi-Tasavvufu-yeniden-dusunmeliyiz-10452-haberi.html

Yılmaz, H. Kâmil. Anahatlarıyla Tasavvufve Tarîkatlar. İstanbul: Ensar Neşriyat, 1994.

Ziadeh, Nicola A. Sanisiyah. Leiden: y.y., 1958. 